\title{
Gender Analysis of Labor and Resources in Greenhouse Vegetable Production in the Antalya Province of Turkey
}

\author{
Robin G. Brumfield ${ }^{1,3}$ \\ Department of Agricultural, Food, and Resource Economics, Rutgers School \\ of Environmental and Biological Sciences, The State University of New \\ Jersey, 55 Dudley Road, New Brunswick, NJ 08901-8520
}

\section{Burhan Ozkan ${ }^{2}$ \\ Department of Agricultural Economics, Faculty of Agriculture, University of Akdeniz, Antalya 07070, Turkey}

Additional index words. women, gender, greenhouse, vegetables, Turkey

\begin{abstract}
The aim of this study was to identify existing gender roles in greenhouse vegetable production in the Antalya Province of Turkey. For this purpose, we conducted face-to-face interviews with the owners of 50 vegetable-producing greenhouses to understand the dominant household structures, activity profiles, information sources, training needs, access to resources, control over resources, and intrahousehold income stream. Activity profiles reflected the hours per day men and women spent on specific greenhouse production and household tasks. We observed access to and control of production resources as well as intrahousehold income streams for the two genders. Compared with men, women had higher illiteracy rates and lower levels of education. They also had overall heavier workloads despite having similar workloads in the greenhouse (productive activities), the difference resulting from household (reproductive activities) which were carried out mainly by women. Women received most agricultural information from neighbors, while men obtained most information from chemical salespeople. Notably, men received some information from the agricultural extension service, but women did not. Women also had less access to and control over productive resources. Furthermore, the intrahousehold income streams in the selected households benefited men more than women. In this study, we compared differences among three independent demographic variables: the age of producers, the level of education of the producers, and years of experience farming against women's ability to prepare the family budget, spend money without asking her spouse, purchase of agricultural inputs, and select which vegetables to produce. Statistically significant links were found between women's age and ability to manage the family budget, education level and ability to make purchase decisions, and years of production experience and ability to select which vegetables to purchase. The results of this study provide evidence for an unequal social structure and show that efforts should be made to increase women's access to and control of production resources, including information from the extension service.
\end{abstract}

Worldwide, women play a key role in agriculture as growers, workers, and entrepreneurs, but almost everywhere, they face more severe constraints than men in accessing productive resources, markets, and services. One reason agriculture is underperforming in

Received for publication 21 June 2016. Accepted for publication 3 Oct. 2016.

This paper was supported by the Scientific Research Projects Administration Unit of Akdeniz University.

A very special thank you to David Wallace, Stacy B. Brody, and Laura Kenny for their insightful and thorough edits, and to Ali Rıza Aktaş for statistical analysis.

${ }^{1}$ Professor and specialist in farm management.

${ }^{2}$ Professor.

${ }^{3}$ Corresponding author. E-mail: brumfiel@njaes. rutgers.edu. elderly of the household), 2) intrahousehold dynamics, i.e., differences between families and households and unequal control over resources between genders, and 3 ) the heterogeneity of household structures, i.e., nonnuclear family.

Women in Development (WID) and Gender and Development (GAD) are two policy models which have described development and women (Momsen, 2004). These policy models are in use by development organizations, such as the Food and Agriculture Organization, to understand women's contributions to agriculture in developing countries. Evidence supports that empowering women is highly conducive to increased agricultural productivity, food security, and nutrition (Meinzen-Dick and Quisumbing, 2013). Women in Development has viewed women as an untapped labor source but has failed to include women's perspectives in planning and policymaking (Karl, 1995). Thus, WID-based policies address practical gender needs, i.e., "what women require to fulfill their roles and tasks" but fail to recognize strategic gender needs, i.e., "what women require to overcome their subordination."

GAD-based policies focus not only on women, but also on "the structure and dynamics of gender relations" and "the totality of women's and men's lives" (Karl, 1995). Thus, the GAD construct has the aim of changing the "structures and process that give rise to women's disadvantage" (Karl, 1995). The GAD model recognizes gender relationships and roles affecting development policies and projects and has acknowledged that women's and men's roles are social constructs.

Generally, women have had inadequate access to and control over economic resources such as land, labor, and capital, and to decision-making processes such as which crops to grow and where to market their products. Many development efforts have failed to consider this uneven access to resources based on gender roles, but reports by the Food and Agriculture Organization show that both governmental and nongovernmental organizations are taking steps to change this (FAO, 1997; FAO, 2011). National and international governing bodies are increasingly integrating gender concerns into policies. Some studies have conducted gender analyses to understand the differences by gender of economies, labor systems, resource allocations, and income. Several studies have pointed out the importance of considering gender roles in terms of intrahousehold distribution of labor, land relations, access and control of resources, and decision-making (Evers and Walters, 2000; Grown et al., 2000; Hansen and Vaa, 2004; Tsikata, 2009; Whitehead, 2002). Lu (2010) showed that gender interaction influences agrarian transition, health, and economic development.

Gender analysis is important because efficiency and productivity are increased when programs are targeted to the actual 
users (Nyakudya et al., 2006). A gender analysis of two private irrigation systems in Carchi, Ecuador, found that women's participation in decision-making was impacted by such factors as children, age, health, and urban vs. rural background (Bastidas, 1999). With more information on actual users, program designers and policymakers can more effectively target their audience and not only improve the lives of users but also agricultural productivity in the region overall.

Agriculture is a major sector in the Turkish economy; one of four people is employed in the agricultural sector (Olhan, 2011). Although women in Turkey have important roles in the agricultural sector, they are not compensated equally; women are paid less than men in agricultural jobs (Davran and Tok, 2011; Ozkan et al., 2000). Previous research shows that the extension system in Turkey has underserved its female audience (Durutan, 1994; Klaver and Kamphuis, 2006).

Kiernan et al. (2012) found that agricultural education in the United States has previously also underserved women farmers, stating in her study of programs for women farmers in Pennsylvania that "women farmers found educational programs in agriculture unwelcoming, if not hostile. Participants and instructors did not take women seriously. Unidirectional learning from 'experts' predominated with little opportunity for hands-on learning. Educational programs focused heavily on a scale of farming that many women did not practice (large operations with single commodities such as swine, beef, dairy, agronomic crops, and turf grass). Agricultural education lacked a focus on women's farms that are characterized by limited acreage; production of vegetables, fruits, cheese, or flowers; diverse herds; use of alternative marketing strategies; and organic and sustainable practices" (Kiernan et al., 2012).

In Turkey, as in many developing countries, women play an important role, but social and economic structures in Turkey allow for social and economic inequality between genders. This has happened despite the secular characteristic of the Republic of Turkey and the fact that women have equal rights under the law, and equally inherent property and land. In 2009, the illiteracy rate in Turkey was $8 \%$, with women representing $80 \%$ of the illiterate population. Two-thirds of illiterate women in Turkey were over 50 years of age, which may indicate that education for women in Turkey is improving (Uysal-Kolasin and Guner, 2010).

The practice of growing food crops, especially horticultural crops, and tending small livestock has emerged as a critical element in food security, and a gender analysis of 91 farms in Sierra Leone found that female-managed farms had higher gross and net returns than male-managed farms (Idowu et al., 2012). Although women make substantial contributions to vegetable production systems in Turkey, no definitive studies on the division of labor between women and men on Turkish vegetable greenhouses have been published. Vegetables produced in greenhouses (glass or plastic) are cash crops in Turkey, the major greenhouse vegetable crops being tomatoes (Solanum lycopersicum), eggplants (Solanum melongena), cucumbers (Cucumis sativus), and peppers (Capsicum annuum). Greenhouses provide many advantages over field-grown vegetables, including higher crop returns and yearround production (Yilmaz et al., 2005).

The primary objective of our study was to investigate the gender situation in greenhouse vegetable production in the Antalya Province of Turkey. We selected Antalya as the target research area of this study because it is the center of Turkish greenhouse vegetable production. Antalya accounts for $43 \%$ of all agricultural land under protective cover in Turkey (TUIK, 2015), and produces $20 \%$ of Turkey's exported fruits and vegetables (Olhan, 2011). Antalya Province was also the highest or second highest producer of nine of Turkey's top 22 vegetables cultivated for their fruit in 2015, including staple crops such as table tomatoes, eggplants, table cucumbers, and bell peppers (TUIK, 2015). The specific aims of the study were to 1) characterize the sample with demographic information, 2) identify existing gender roles in vegetable farming systems to determine how women's and men's labor was valued, and 3) explore the effects of various factors on women's ability to make production decisions independently. We expected to find more demands on women's time, more constraints on women's abilities to access and control resources related to production, and some significant correlations between demographic variables and women's ability to make key decisions about production. The information gathered in this study concerning differences in gender roles could be used to develop extension programs that address the needs of women farmers and improve the local agricultural system.

\section{Materials and Methods}

Data collection. We collected data for this study from vegetable farms in the Antalya Province via a questionnaire delivered during face-to-face interviews. Of the 14 districts in the province, we selected the three districts producing the greatest volumes of greenhouse vegetables as representative districts. In collaboration with the local officials of the Provincial Directorate of Food, Agriculture and Livestock, we selected the five villages with the greatest volume of greenhouse production to sample within each district. The Provincial Directorate of Food, Agriculture and Livestock believed that sample villages and greenhouse sizes are representative of the Antalya Province. Using greenhouse size as the variable, we randomly selected a total of 50 farms from the villages by using the stratified random sampling method (Yamane, 1967). Most farms in Antalya, and all farms included in the study, had at least one greenhouse; and small-scale farming was dominant in the province. Greenhouse vegetables were the most important crops grown in Antalya. The farms that we surveyed had 4.5 members per household or 215 people combined. This represents $0.129 \%$ of the 167,226 people employed in agriculture in Antalya (TUIK, 2015). Each woman and man 15 years of age and older who was present in the household at the time of the visit was interviewed. We stratified the sample households into two greenhouse size groups: small (1-2000 $\left.\mathrm{m}^{2}\right)$ and large (greater than $2000 \mathrm{~m}^{2}$ ). We chose the size cutoff to be a round number which roughly divided the sample in half. It is also near the average greenhouse size in Antalya of $2180 \mathrm{~m}^{2}$ (Yilmaz et al., 2005). The number of sample households was 28 in the group of small greenhouses and 22 in the large group.

This study used an Analytical Framework for gender analysis (FAO, 1992), which was developed by a Harvard University research team (Overholt et al., 1984). We collected data for this research using a questionnaire method from 77 adult female farmers and 78 adult male farmers in the random sample of 50 vegetable farms in Antalya Province, Turkey.

We directed the questionnaire used in this study (Supplemental Appendix) to greenhouse vegetable producers and included questions concerning 1) household structure (age, gender, marital status, educational level, family size, number of generations in the household, number and ages of family members who worked in greenhouse production, sources of information, and training needs); 2) activity profile of hours per day spent on productive activities, which include specific farm activities [greenhouse vegetable production, open field vegetable production, other field crop production (wheat, cotton, maize, and sesame), fruit production, animal husbandry, processing food for sale, marketing], offfarm activities (wage off-farm labor and exchange labor), and reproductive activities, or household tasks (food storage/processing; child care; domestic tasks of cooking, cleaning the house and surroundings, washing and mending clothes; and house building and repair); 3) access to resources of land, technology (modern and traditional), labor (family and wage), capital, cooperatives, credit, cattle, and poultry; and 4) control over aforementioned resources. Access to resources means that the person may use a resource, whereas control implies that the person can own or make decisions regarding a resource. Hassan et al. (2006) reviewed previous gender analysis studies and found that a combination of quantitative and qualitative research methodologies, as used in this study, offset bias and allowed for greater insight into a plurality of viewpoints and interests.

Data analysis. We tested hypotheses for each of three independent variables: 1) the age of female producers, 2) the level of education of the female producers, and 3) years of experience farming as a female producer. We tested each of these independent variables separately against four dependent variables which included the woman's ability to 1) prepare the family budget, 2) spend 
money without asking her spouse, 3) purchase agricultural inputs, and 4) select which vegetables to produce. All variables were categorical; we converted age into four categories $(0-25,26-35,36-50$, and 51+ years) and years of experience into three categories (1-5, 6-10, and $11+$ years).

We analyzed the data collected from the questionnaire using chi-square test, and Fisher's exact test (in the case of expected value less than 5) (Cramer, 1998). We tested the following hypotheses separately for each question:

$\mathrm{H}_{0}$ : No differences existed among how participants of different demographics responded to the questions posed in the study. $\mathrm{H}_{0}: \mathrm{u}=\mathrm{u}_{0}$

$\mathrm{H}_{\mathrm{A}}$ : Differences existed among how participants of different demographics responded to the questions posed in the study. $\mathrm{H}_{\mathrm{A}}: \mathrm{u} \neq$ $u_{0}$ (two-tailed test).

We evaluated the data obtained in this study using SPSS 19.0. In the evaluation, we calculated the frequency and percentage of responses to the questionnaire options for each question. We used a 0.10 significance level. We carried out statistical analysis based on the responses of 77 women farmers (75 usable surveys). We used the chi-square test to determine whether there was a significant difference between the expected frequencies and the observed frequencies in our categories, i.e., did the number of individuals in each category differ significantly from the number expected: is this difference between the expected and observed due to sampling variation, or is it a real difference?

\section{Results and Discussion}

\section{Demographics}

Farm size. We divided targeted households into two groups based on physical greenhouse size, those $2000 \mathrm{~m}^{2}$ or less (small) and those greater than $2000 \mathrm{~m}^{2}$ (large). The average size of selected farms was 2.4 ha. The majority of the farm area was devoted to field crops $(81.4 \%)$, excluding vegetables. The average greenhouse size was $2172 \mathrm{~m}^{2}$, with sizes ranging from 480 to $7000 \mathrm{~m}^{2}$ (Table 1). The majority of greenhouse structures were glass $(71.6 \%)$ and $28.4 \%$ were plastic. In this study, producers used cover crops for all crops other than vegetables. As vegetables were planted as cash crops, the planting size was on a commercial scale. Average yields for tomatoes were 100 tons per ha. Thirty-six percent of households practiced doublecropping of their vegetable crops. Common double-cropping plantings were tomatotomato $(40 \%)$, tomato-pepper $(30 \%)$, and tomato-cucumber $(30 \%)$.

Household size. The average family size of selected households was 4.5 people (Table 2). About $48.0 \%$ of the population was female. On average, each home had 2.1 women and 2.3 men. The majority of females

Table 1. The average area by production activity ${ }^{z}$ and greenhouse size of 50 surveyed farming households in Antalya Province, Turkey. Greenhouses are considered small if they have areas of 1-2000 $\mathrm{m}^{2}$ and large if they have areas $>2000 \mathrm{~m}^{2}$.

\begin{tabular}{lcccc}
\hline & \multicolumn{3}{c}{ Greenhouse size } \\
\hline & Small $\left(\mathrm{m}^{2}\right)$ & Large $\left(\mathrm{m}^{2}\right)$ & Mean $\left(\mathrm{m}^{2}\right)$ & Percent of total \\
\hline Greenhouse area & 1,190 & 3,422 & 2,172 & 8.9 \\
Glass & 1,030 & 2,226 & 1,556 & 6.4 \\
Plastic & 161 & 1,196 & 616 & 2.5 \\
Open vegetable area & 1,214 & 1,227 & 1,220 & 5.0 \\
Field crops area & 11,786 & 29,818 & 19,720 & 81.4 \\
Orchard area & 304 & 2,136 & 1,110 & 4.7 \\
Total & 14,493 & 36,602 & 24,221 & 100.0 \\
\hline
\end{tabular}

${ }^{2}$ Production activities in Antalya Province include greenhouses, vegetable production in open fields, field crops, and orchards.

Table 2. The composition and size of household by age and gender differentiated by greenhouse size of 50 surveyed farming households in Antalya Province, Turkey. Greenhouses are considered small if they have areas of $1-2000 \mathrm{~m}^{2}$ and large if they have areas $>2000 \mathrm{~m}^{2}$.

\begin{tabular}{|c|c|c|c|c|c|}
\hline \multirow[b]{3}{*}{ Age by gender } & \multicolumn{5}{|c|}{ Greenhouse size groups } \\
\hline & \multirow{2}{*}{$\frac{\text { Small }}{\text { (Number) }}$} & \multirow{2}{*}{$\frac{\text { Large }}{\text { (Number) }}$} & \multicolumn{2}{|c|}{ Mean } & \multirow{2}{*}{$\begin{array}{l}\text { Percent } \\
\text { of total }\end{array}$} \\
\hline & & & $\overline{\text { (Number) }}$ & $\overline{\text { (Percent) }}$ & \\
\hline \multicolumn{6}{|l|}{ Females by age } \\
\hline$<14$ & 0.6 & 0.5 & 0.5 & 24.3 & 11.7 \\
\hline $15-64$ & 1.4 & 1.6 & 1.5 & 70.6 & 33.6 \\
\hline $65+$ & 0.1 & 0.1 & 0.1 & 5.6 & 2.7 \\
\hline Total females per household & 2.1 & 2.2 & 2.1 & 100.0 & 48.0 \\
\hline \multicolumn{6}{|l|}{ Males by age } \\
\hline$<14$ & 0.6 & 0.7 & 0.7 & 28.4 & 14.5 \\
\hline $15-64$ & 1.6 & 1.6 & 1.6 & 68.1 & 35.4 \\
\hline $65+$ & - & 0.2 & 0.1 & 2.5 & 1.8 \\
\hline Total males per household & 2.3 & 2.4 & 2.3 & 100.0 & 52.0 \\
\hline \multicolumn{6}{|l|}{ Persons per household } \\
\hline $2-3$ & 6 & 3 & 9 & & 18.0 \\
\hline $4-6$ & 21 & 18 & 39 & & 78.0 \\
\hline $7-8$ & $\underline{1}$ & $\underline{1}$ & $\underline{2}$ & & $\underline{4.0}$ \\
\hline Total & $2 \overline{8}$ & $2 \overline{2}$ & $5 \overline{0}$ & & $10 \overline{0.0}$ \\
\hline Average household size & 4.3 & 4.6 & 4.5 & - & 100.0 \\
\hline
\end{tabular}

and males were between 15 and 64 years of age, suggesting that most of the vegetables were produced by producers within this age bracket. About $26.5 \%$ of total family members were under 14 years of age and only $4.5 \%$ of members were over 64 years of age.

Turkish producers are much younger than farmers in the United States where the average age of farmers in the last U.S. Department of Agriculture Census of Agriculture was 56.3 ; only $1.5 \%$ were under 25 years of age, and $57.0 \%$ were over 54 years of age (U.S. Department of Agriculture, 2012), whereas $28.5 \%$ of Turkish farmers were under 25 years of age and only one-third were over 50 years of age in the last Turkish Census of Agriculture (TUIK, 2015). The majority of the households in our survey consisted of four to six persons (Table 2). This was followed by households of two to three persons, and seven to eight persons.

Educational level of labor working in vegetable production. The highest level of education attained by the majority of females $(62.0 \%)$ was primary school graduation. However, the illiteracy rate for women in the survey was relatively high $(18.3 \%)$ compared with Turkey's overall female illiteracy rate of $8.2 \%$ (CIA, 2015).

On average, 1.4 females and 1.6 males worked in vegetable production per household. Females in the surveyed farms received less formal education than the men. Unlike females, no males in the selected farms were illiterate. Only $3.8 \%$ of males had no type of diploma. The majority of both the males $(57.7 \%)$ and females $(62.0 \%)$ had completed primary school. No females had received a university degree, whereas $5.2 \%$ of men had finished university studies. Lower levels of education and higher rates of illiteracy than men may explain why women tended to rely more heavily on neighbors and their husbands rather than other sources of information such as chemical salespeople and the extension service (Table 3). From question 10 in the survey (Supplemental Appendix), the average number of males older than 6 years of age living in the household and working in vegetable production was 2.0 males per household.

Labor was almost entirely provided by family members. Sources of labor on the farms were the household members and voluntary exchange labor from neighbors. On average, 3.0 people over 14 years of age worked in vegetable production per household. The number of people over 6 years of age working in vegetable production was 3.8 per household, indicating that household members between 6 and 14 years of age did indeed contribute to production.

Information sources and training needs. Women and men obtained information on 
Table 3. Sources of information women and men use with regard to vegetable production and marketing by greenhouse size for 50 surveyed farming households in Antalya Province, Turkey. Greenhouses are considered small if they have areas of 1-2000 $\mathrm{m}^{2}$ and large if they have areas $>2000 \mathrm{~m}^{2}$.

\begin{tabular}{|c|c|c|c|c|c|c|}
\hline $\begin{array}{l}\text { Information sources } \\
\text { Greenhouse size groups }\left(\mathrm{m}^{2}\right)\end{array}$ & \multicolumn{3}{|c|}{$(\mathrm{N}=77$ women $)$} & \multicolumn{3}{|c|}{$(\mathrm{N}=78$ men $)$} \\
\hline Chemical salespeople & 33.4 & 25.9 & 30.2 & 95.4 & 87.8 & 92.4 \\
\hline Extension service & - & - & - & 18.2 & 27.2 & 22.0 \\
\hline Technicians & - & - & - & 6.8 & 9.1 & 7.8 \\
\hline Others $^{z}$ & - & 3.7 & 6.4 & 4.6 & 12.2 & 7.8 \\
\hline
\end{tabular}

${ }^{\mathrm{z} F a m i l y ~ m e m b e r s, ~ n e i g h b o r s, ~ v i l l a g e ~ t e c h n i c i a n, ~ c o o p e r a t i v e s . ~}$

agricultural production from different sources. The primary source of information for women was neighbors, followed by chemical salespeople, and their husbands (Table 3). In contrast, men received most of their information from chemical salespeople followed by neighbors, extension service, technicians, and others (Table 3). These results indicate that, though nearly all interviewees received some form of help and advice, the levels of assistance varied considerably. Neighbors (local producers) were the main information source for women. Women consulted other producers more extensively than men did, fostering a potential information-sharing network. None of the women in our study considered the extension service to be an important source of advice. It appeared that the extension service outreach related to vegetable production was mainly directed to men. Gender-responsive programs that account for constraints on women's time and access to resources have demonstrated greater degrees of success improving outcomes in agricultural development and gender equality (Gates, 2014). Brumfield et al. (2016) found that women farmers in Turkey who had completed educational training in farm business management would prefer more convenient hours, such as evening, and no more than 2-3 sessions per week. More research is needed to discover ways to overcome the obstacles such as child care needs and family and farm obligations that women face when accessing extension services.

Income-generating activities. Farm income $(93.4 \%$ of total income) was the main source of income for the households surveyed. Income from vegetable production $(73.6 \%$ of total income) provided the largest portion of farm income (Table 4). Vegetable production was an important income-generating activity in the selected households, whereas income generated from animal husbandry (i.e., poultry, dairy production, meat production) was not very important. Survey participants raised animals mainly for home consumption, and not for marketing off-farm. Off-farm agricultural income was rare $(3.2 \%)$ and generally provided by men. The share of nonagricultural income in the total family income was only $6.6 \%$. Even though Antalya Province is the main tourist region in Turkey, nonagricultural income was uncommon in the surveyed households and these jobs were held only by men.

Table 4. Distribution of family income sources based on gender for 50 surveyed farming households in Antalya Province, Turkey.

\begin{tabular}{lccr}
\hline Source of income & Women (percent) & Men (percent) & Total (percent) \\
\hline 1.Agricultural farm income & 37.9 & 52.3 & 90.2 \\
Vegetables & 33.6 & 40.0 & 73.6 \\
Other crops & 2.1 & 12.1 & 14.3 \\
Animal husbandry & 1.8 & - & 1.8 \\
Processed food for sale & 0.4 & 0.1 & 0.5 \\
2. Off-farm income & 0.1 & 3.1 & 3.2 \\
3. Agricultural income $(1+2)$ & 38.0 & 55.3 & 93.4 \\
4. Nonagricultural income & 0.0 & 6.6 & 6.6 \\
5. Total family income $(3+4)$ & 38.1 & 61.9 & 100.0 \\
\hline
\end{tabular}

Table 5. Minutes per day and percentage of working time devoted to various activities by women versus men for 50 surveyed farming households in Antalya Province, Turkey.

\begin{tabular}{|c|c|c|c|c|c|c|}
\hline \multirow[b]{3}{*}{ Activities } & \multicolumn{6}{|c|}{ Total work per day } \\
\hline & \multicolumn{2}{|c|}{ Women } & \multicolumn{2}{|c|}{ Men } & \multicolumn{2}{|c|}{ Total } \\
\hline & Minutes & Percent & Minutes & Percent & Minutes & Percent \\
\hline A. Farming & 166.0 & 51.2 & 158.0 & 48.8 & 324 & 100 \\
\hline 1. Greenhouse vegetable production & 101.4 & 52.4 & 91.9 & 47.6 & 193.3 & 100 \\
\hline 2. Open field vegetable production & 2.5 & 39.8 & 3.8 & 60.2 & 6.3 & 100 \\
\hline 3. Other field crop production & 5.2 & 19.0 & 22.3 & 81.0 & 27.5 & 100 \\
\hline 4. Fruit production & 0.2 & 8.1 & 1.9 & 91.9 & 2.1 & 100 \\
\hline 5. Animal husbandry & 52.2 & 94.1 & 3.3 & 5.9 & 55.5 & 100 \\
\hline 5.1. Cattle & 37.9 & 94.0 & 2.4 & 6.0 & 40.3 & 100 \\
\hline 5.2. Poultry & 14.3 & 94.1 & 0.9 & 5.9 & 15.2 & 100 \\
\hline 6. Processing food for sale & 0.6 & 100.0 & - & - & 0.6 & 100 \\
\hline 7. Marketing (crops) & 1.0 & 3.3 & 29.7 & 96.7 & 30.7 & 100 \\
\hline 8. Wage labor (off-farm) & 0.4 & 13.7 & 2.3 & 86.3 & 2.7 & 100 \\
\hline 9. Exchange labor & 2.6 & 47.9 & 2.8 & 52.1 & 5.4 & 100 \\
\hline B. Family & 361.1 & 92.2 & 30.8 & 7.8 & 391.9 & 100 \\
\hline 1. Food storage/processing & 13.3 & 95.5 & 0.6 & 4.5 & 13.9 & 100 \\
\hline 2. Child care & 106.4 & 83.9 & 20.4 & 16.1 & 126.8 & 100 \\
\hline 3. Domestic tasks & 240.6 & 96.4 & 8.9 & 3.6 & 249.5 & 100 \\
\hline 3.1. Cooking & 132.4 & 95.5 & 6.3 & 4.5 & 138.7 & 100 \\
\hline $\begin{array}{l}\text { 3.2. Cleaning house and } \\
\text { surroundings }\end{array}$ & 75.5 & 96.6 & 2.6 & 3.4 & 78.1 & 100 \\
\hline 3.3. Washing clothes & 31.1 & 100.0 & - & - & 31.1 & 100 \\
\hline 3.4. Mending clothes & 1.6 & 100.0 & - & - & 1.6 & 100 \\
\hline 4. House building and repair & 0.8 & 47.9 & 0.9 & 52.1 & 1.7 & 100 \\
\hline C. Total $(\mathrm{A}+\mathrm{B})$ minutes & 527.1 & 73.6 & 188.8 & 26.4 & & 100 \\
\hline Hours & 8.8 & 73.6 & 3.2 & 26.4 & & 100 \\
\hline
\end{tabular}

\section{Gender analysis}

Activity profile. An activity profile is based on gender division of labor. An activity profile identifies who performs what activities, when, and where (FAO, 1992). The activity profile reflects the total labor burdens of men and women and the relations between tasks. In the activity profile, farming and household activities are delineated by hours per day spent on specific tasks. In this study, farming (productive) activities included greenhouse vegetable production, open field vegetable production, other field crop production, fruit production, animal husbandry, processing food for sale, marketing, wage, off-farm labor, and exchange labor. Family (reproductive) activities included food storage/processing; child care; domestic tasks of cooking, cleaning the house and surroundings, washing clothes, and mending clothes; and house building and repair.

The following inferences can be drawn from the results presented in Table 5 based on reporting by men and women themselves. Women worked $8.8 \mathrm{~h}$ per day while men worked only $3.2 \mathrm{~h}$ per day. The main difference in workloads between women and men came from family responsibilities, where 
women performed the dominant share of the work. This discrepancy is common in many countries (FAO, 2004). According to our data from Antalya, women devoted $361.1 \mathrm{~min}$ to the family tasks, whereas men dedicated only $30.8 \mathrm{~min}$ for the same type of work. If family activities are ignored, women's and men's workloads for the farming activities were similar. Women and men spent 166.0 and $158.0 \mathrm{~min}$, respectively, on farming activities per day. Women were mainly responsible for vegetables, cattle and poultry production, and for processing food for sale. Men dealt with all crops produced on the farm and crop marketing. Vegetables, particularly greenhouse vegetables, were produced for market. Generally, men drove to the wholesale market to sell their vegetable products.

It is very clear that household tasks (food storage and processing, child care, cooking, cleaning the house and surroundings, washing clothes, mending clothes, and house building and repair) were considered to be "women's work." Thus, women's overall workloads were heavier than those of men. According to a sample profile of a man's day, men also rise and go to bed earlier, spend at least 30 min more watching television, and take 90 min to visit the café. It is possible that men are spending time in management functions that they didn't report. Perhaps some of this takes place at the café when they are talking to other men. The inequality between men's and women's household workloads illustrate that efforts need to be made to deconstruct the societal constructs of gender and convince men to help in the house, or technologies for reducing household labors need to be shared with women in the province. Also, if extension is to be an important information source, it needs to consider the demands on women's time when designing educational programs.

\section{Profile of resources and benefits}

Women farmers, workers, and entrepreneurs throughout the world face more severe constraints than men in accessing productive resources, markets, and services. This "gender gap" hinders their productivity and reduces their contributions to agriculture (FAO, 2011). A profile of resources and benefits examines what resources were available to people to carry out their activities, what benefits they derived from these activities, who had access to resources and benefits, and who controlled them (FAO, 1992). In this study, we asked who had access to resources of land, technology (modern and traditional), labor (family and wage), capital, cooperatives, credit, cattle, and poultry. A second set of questions asked who had control over these same resources.

Access to resources. Access means people can use, but may not own or decide how to use resources in farming activities. Resources include land, capital, labor, livestock, credit, cooperatives, and technology. Both women and men had some access to land, but women's access was about one-third compared with two-thirds for men. Generally, women had less access to farming resources compared with men. For example, women had less access to land, cooperatives, and credit than men in general (Table 6). Women's access to land is limited in many countries, even in those nations with legislation guaranteeing women the right to access this resource (FAO, 2004). Although women had more access to traditional technology than men, men had considerably more access to modern technology than women (women had very little access to modern technology). Women had no access to capital, but had more access to cattle and poultry than men. Women had less access to credit and cooperatives than to livestock.

Producers obtained credit from two official sources: either from the agricultural bank which required the producer to deposit his/ her land titles with the bank or from a cooperative which also needed such security for large cash loans. However, the cooperative may have provided inputs for agricultural crops on the understanding that the loan would be repaid upon the harvest of the crop. Because of the necessity for securities (land titles), not all producers were able to obtain credit. Women typically have little to no control over land, as discussed in the next section. Additionally, lenders did not grant new loans unless the first loan was paid back.

Control over resources. Control over resources, or the ability to own them or make decisions concerning them, differed according to gender. For instance, although some women had access to land, their control over land was very low. Little or no control over land may then prevent women from accessing credit from a bank or cooperative. Women's control over modern technology was low, but women had high control over traditional technology (Table 7). Control over family labor was typically held by men.

Women did not have any control over capital or credit. As mentioned earlier, some women had access to credit (Table 6). However, these women could not decide how the credit was to be used. Women's control over cattle was less than that of men, but they had more control than men over poultry. In summary, women's control over farm resources was lower than their access to the resources, and except for traditional technology and poultry, women's control was lower than men's control of resources.

Benefits and uses of resources. Benefits constitute the outputs of income, food, savings, status, land rights, productivity, labor, experience, and inputs. The intrahousehold income stream is defined as the pattern of distribution and use of benefits within households (FAO, 1992). Women did not receive any benefits from cooperatives and credit (Table 8). Benefits and use patterns for women in order of importance were as follows: food, productivity, labor, income, experience, and saving, with no benefits and use related to status, land rights, and input. The benefits and use patterns for men in order of importance were income, input, food, experience, productivity, labor, status, and land rights, with no benefits and use related to saving. It can be concluded that men's benefits from the farm resources were much higher than women's benefits.

\section{Women's decision-making abilities}

As we explained in the data analysis, we surveyed households to determine who makes decisions regarding family budget preparation, spending money, vegetable selection, and agricultural inputs. Families varied as to who made decisions about managing the farm. We asked who made the decision, i.e., woman, husband, husband and wife, family, or family elders. Most frequently, the husband made the decisions followed closely by the family making the

Table 6. Gender profile on access to resources (number and percentage) for 50 surveyed farming households in Antalya Province, Turkey.

\begin{tabular}{|c|c|c|c|c|c|c|c|c|}
\hline \multirow{2}{*}{ Resources } & \multicolumn{4}{|c|}{ Women } & \multicolumn{4}{|c|}{ Men } \\
\hline & \multicolumn{2}{|c|}{ Access } & \multicolumn{2}{|c|}{ Do not access } & \multicolumn{2}{|c|}{ Access } & \multicolumn{2}{|c|}{ Do not access } \\
\hline 1. Land & 26 & 35.1 & 48 & 64.9 & 46 & 59.0 & 32 & 41.0 \\
\hline 2.1. Modern & 3 & 4.0 & 72 & 96.9 & 60 & 76.9 & 18 & 23.1 \\
\hline 2.2. Traditional & 62 & 83.8 & 12 & 16.2 & 1 & 9.1 & 30 & 90.9 \\
\hline \multicolumn{9}{|l|}{ 3. Labor } \\
\hline 3.1. Family & 71 & 94.7 & 4 & 5.3 & 78 & 100.0 & - & - \\
\hline 5. Cooperatives & 14 & 18.7 & 61 & 81.3 & 32 & 41.0 & 46 & 59.0 \\
\hline 6. Credit & 9 & 12.0 & 66 & 88.0 & 27 & 34.6 & 51 & 65.4 \\
\hline 7. Cattle & 25 & 33.3 & 50 & 66.7 & 12 & 15.4 & 66 & 84.6 \\
\hline 8. Poultry & 30 & 40.0 & 45 & 60.0 & 5 & 6.4 & 73 & 93.6 \\
\hline
\end{tabular}


Table 7. Gender profile on control over resources (number and percentage) for 50 surveyed farming households in Antalya Province, Turkey.

\begin{tabular}{|c|c|c|c|c|c|c|c|c|}
\hline \multirow{2}{*}{ Resources } & \multicolumn{4}{|c|}{ Women } & \multicolumn{4}{|c|}{ Men } \\
\hline & \multicolumn{2}{|c|}{ Have control } & \multicolumn{2}{|c|}{ No control } & \multicolumn{2}{|c|}{ Have control } & \multicolumn{2}{|c|}{ No control } \\
\hline 1. Land & 6 & 8.0 & 69 & 92.0 & 53 & 67.9 & 25 & 32.1 \\
\hline 2.1. Modern & 5 & 6.7 & 70 & 93.3 & 59 & 75.6 & 19 & 24.4 \\
\hline 2.2. Traditional & 60 & 80.0 & 15 & 20.0 & 8 & 10.3 & 70 & 89.7 \\
\hline \multicolumn{9}{|l|}{ 3. Labor } \\
\hline 3.1 Family & 17 & 22.7 & 58 & 77.3 & 48 & 66.7 & 26 & 33.3 \\
\hline 6. Cattle & 5 & 6.4 & 73 & 93.6 & 46 & 61.3 & 29 & 38.7 \\
\hline 7. Poultry & 31 & 40.8 & 45 & 59.2 & 3 & 3.8 & 75 & 96.2 \\
\hline
\end{tabular}

Table 8. Gender profile on types of benefits and uses of resources ${ }^{z}$ for 50 surveyed farming households in Antalya Province, Turkey.

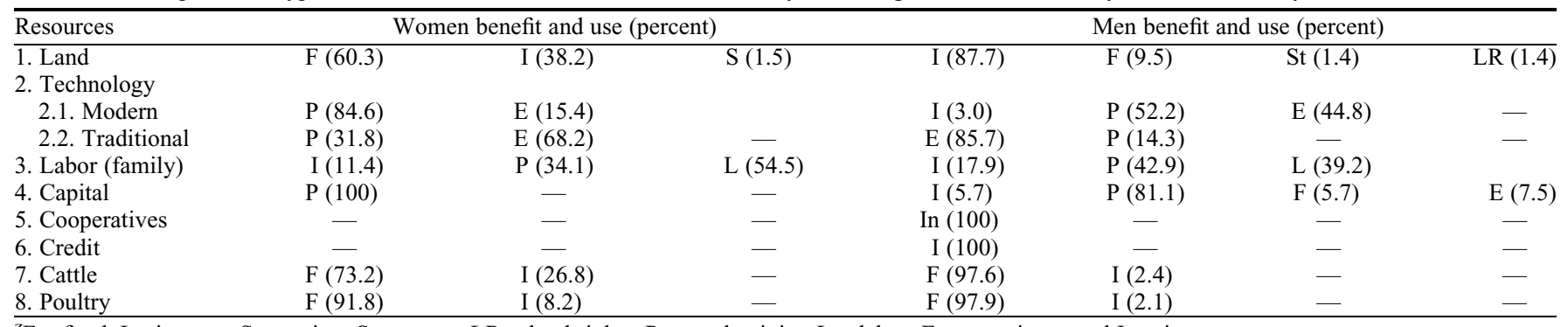

${ }^{\mathrm{z}} \mathrm{F}=$ food, $\mathrm{I}=$ income, $\mathrm{S}=$ saving, $\mathrm{St}=$ status, $\mathrm{LR}=$ land rights, $\mathrm{P}=$ productivity, $\mathrm{L}=$ labor, $\mathrm{E}=$ experience and $\mathrm{In}=$ input.

decisions jointly. In other families, wives and husbands made the decision jointly, the woman made the decision alone, or the family elders made the decision.

Age. Differences in answers between women farmers based on age group and experience in managing the family budget were statistically significant $(P=0.072<$ 0.10 Pearson chi square, Fisher's exact test) (Table 9). The older women were more likely to manage the family budget themselves, whereas the younger women were more likely to manage the family budget with their husbands or with their family. Differences in women farmers' answers according to age groups and their ability to spend money without asking husbands, the ability to purchase agricultural inputs, and the ability to make decisions regarding the choice of vegetables to produce were not statistically significant (Table 9).

Level of education. Differences in answers between women farmers based on the level of education and the ability to purchase agricultural inputs were statistically significant $(P=0.056<0.10$ Pearson chi square, Fisher's exact test) but did not follow a clear pattern. In the surveyed families, the illiterate women purchased agricultural inputs themselves or made those purchase decisions with family elders. In families where the woman had a primary school education, the husband made the decisions on which agricultural inputs to purchase. In families where the women had at least a high school education, they made purchase decisions with the family. It is unclear why the illiterate women appeared to have the most independence when making input purchase decisions, and it may be that a correlation across independent variables (age, education, and years of production experience) affected these results.
We observed no significant statistical differences among women farmers based on level of education in managing the family budget, the ability to spend money without asking her husband, and the ability to choose which vegetables to produce (Table 9).

Years of production experience. Differences in answers between women farmers based on years of production experience and choice of which vegetables to produce were statistically significant $(P=0.039<0.10$ Pearson chi square, Fisher's exact test). As would be expected, the more years of production experience the women had, the more likely they were to select which vegetables to produce. We did not observe statistically significant differences in women farmers' production experience and the authority to manage the family budget, the authority to make decisions about purchase decisions without asking permission from her husband, and the ability purchase agriculture inputs (Table 9).

\section{Conclusions}

Wholesale markets, dominated by middlemen, were the main marketing channels for greenhouse vegetable producers. Producers, both male and female, received fairly low prices for their products and had very little marketing power. Price instability, high interest rates, lack of capital, and lack of coordination between producers through the marketing process were commonly cited by producers as problems. The main characteristic of the vegetable production system was incorporation of family labor widely. In accordance with these characteristics, the extension service in the study area showed two major constraints. First, the local extension service reached a limited number of producers, and second, the extension service focused mostly on male and high-income producers. The extension service in the Antalya Province has not reached women who participate in greenhouse vegetable production, and ranks below chemical salespeople and neighbors for men as a source of information. Thus, extension service programs should be developed to provide information on production, business management, and marketing to both men and women. Turkey already employs female extension agents. This may help women farmers feel more comfortable interacting with extension.

Time constraints on women remain. Programs targeted to women should be scheduled with the activity profile in mind. For instance, women may visit neighbors in the evening. A program targeted to women producers could be scheduled for this time at a villager's home or local school. Information could also be shared at a $G \ddot{U} N$, which is a weekly meeting of women, common in Turkish villages. At such meetings, women may also be able to develop more formal organizations. Agricultural programs focused on the formation and strengthening of women's organizations in Costa Rica and Honduras have been successful (FAO, 1997). Programs targeted to women should focus on increasing access to and use of modern technology as well as decreasing the high rate of illiteracy. Information must be presented in such a way that it is accessible to all women, regardless of level of education. Programs targeted to women are likely to have a large impact because, as shown in this study, women often share information with their neighbors. Likewise, because women bear major responsibility for household activities, extension service programs in family and consumer education should be targeted to 


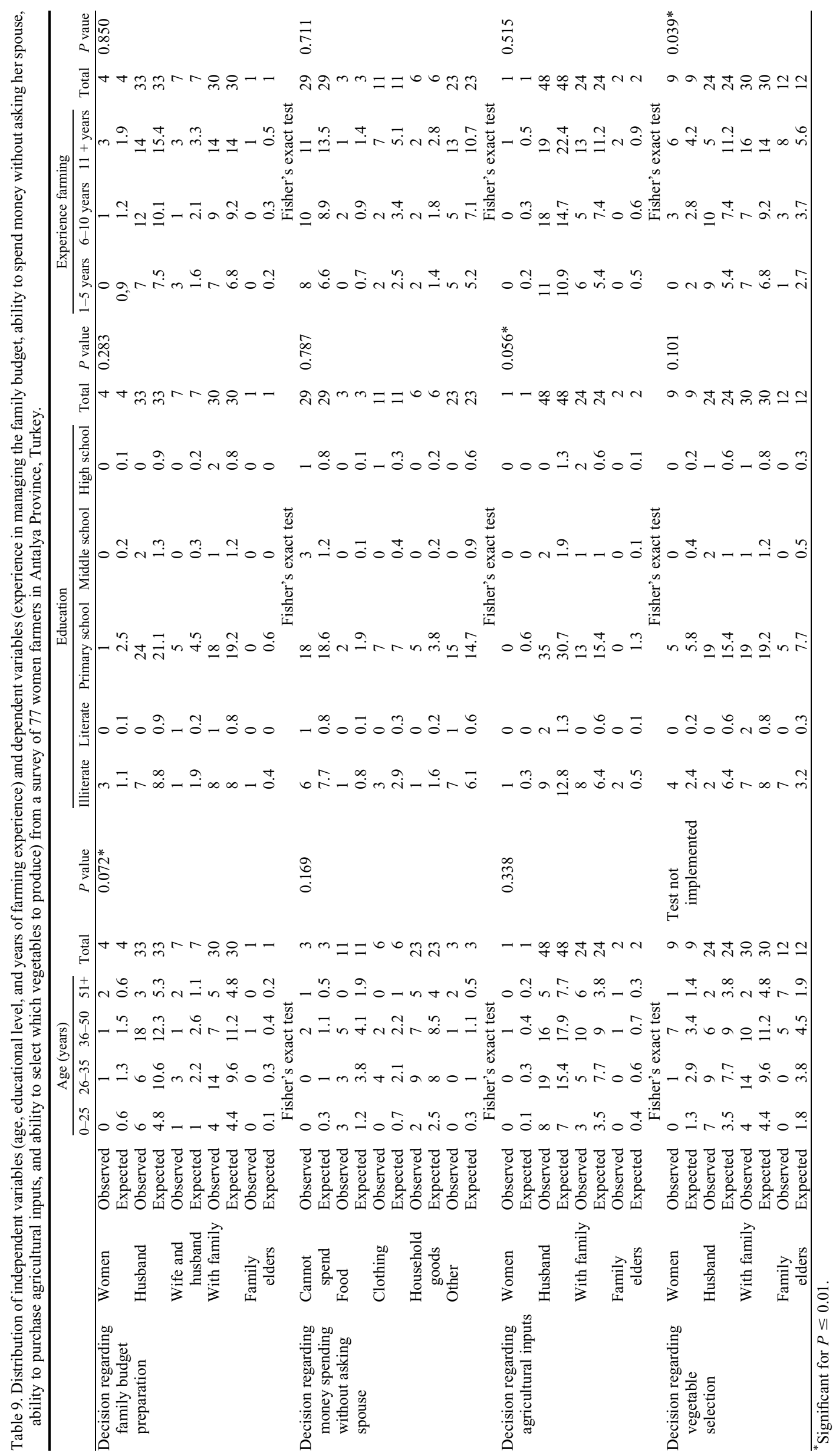


women to help make these functions more efficient and lessen the labor burden for women.

Women had limited access to and absolutely no control of credit. Therefore, Turkey's agricultural credit cooperative should develop programs targeted to women to provide credit and training on managing credit because women's contributions to greenhouse businesses were equal to those of men. Women received no benefits from agricultural cooperatives. Marketing cooperatives were weak or nonexistent for greenhouse producers, both male and female. The Turkish Ministry of Food, Agriculture and Livestock should consider developing programs that help to establish cooperatives so that small producers can collectively purchase inputs and market their products. Women tended to be involved in direct marketing activities while men managed wholesale marketing functions. Thus, cooperatives that market directly to consumers, perhaps to tourists visiting Antalya, should be considered in the Antalya Province.

\section{Literature Cited}

Bastidas, E.P. 1999. Gender issues and women's participation in irrigated agriculture: The case of two private irrigation canals in Carchi, Ecuador. Research Report 31. International Water Management Institute, Colombo, Sri Lanka. 14 June 2016. <http://www.iwmi. cgiar.org/Publications/IWMI_Research_Reports/ PDF/pub031/Report31.pdf $>$.

Brumfield, R.G., B. Özkan, and J. Carleo. 2016. The positive impacts on Turkish women farmers of an all-female agriculture and business management training pilot program. Acta Hort. (ISHS) 1132:81-88. 22 Sept. 2016. <http:// www.actahort.org/books/1132/1132 11.htm>.

Central Intelligence Agency (CIA). 2015. The World Factbook. 14 June 2016. <https://www. cia.gov/library/publications/resources/the-worldfactbook/docs/faqs.html>.

Cramer, D. 1998. Fundamental statistics for social research: Step-by-step calculations and computer techniques using SPSS for Windows. Routledge, New York, NY.

Durutan, N. 1994. Agricultural extension for women Cahiers Options Méditerranéennes 2(4):77-88. 14 June 2016. $<\mathrm{http}: / /$ ressources.ciheam.org/om/ pdf/c02-4/94400046.pdf>.

Evers, B. and B. Walters. 2000. Extra-household factors and women farmers' supply response in SubSaharan Africa. World Dev. 28(7):1341-1345.
Food and Agriculture Organization (FAO). 1992. Women in agricultural development. No. 7. The FAO Gender Analysis Training. Programme for Professional Staff. FAO, Rome, Italy.

Food and Agriculture Organization (FAO). 1997. Gender and participation in agricultural development planning: Key issues for ten case studies. Women in Development Service of the FAO. FAO, Rome, Italy. 14 June 2016. <http:// www.fao.org/docrep/X0254E/x0254e00.htm\# TopOfPage>.

Food and Agriculture Organization (FAO). 2004 Rural households and resources: A guide for extension workers. Socio-Economic and Gender Analysis Programme of the FAO. FAO, Rome, Italy.

Food and Agriculture Organization (FAO). 2011. The state of food and agriculture 2010-2011: Women in agriculture: Closing the gender gap for development. FAO, Rome, Italy. 14 June 2016. <http:// www.fao.org/docrep/013/i2050e/i2050e00.htm>.

Gates, M.F. 2014. Putting women and girls at the center of development. Science 345:12731275. 14 June 2016. <http://www.sciencemag. org/content/345/6202/1273.full>.

Goldey, P., L.B. Shelly, M. Adrienne, and M. Rachel. 1997. Approaches to address gender specific needs in relation to access to technological change. Agr. Syst. 55(2):155-172.

Grown, C., D. Elson, and N. Cagatay. 2000 Introduction. World Dev. 28(7):1145-1156.

Hansen, K.T. and M. Vaa. 2004. Introduction. In K.T. Hansen and M. Vaa (eds.). Reconsidering informality: Perspectives from urban Africa Nordiska Africa Institute, Uppsala, Sweden.

Hassan, M.Z.Y., T. Ali, and M. Ahmad. 2006. A brief review of various gender analysis methodologies. J. Anim. Plant Sci. 16(3-4):114 117. 14 June 2016. <http://www.thejaps.org. pk/docs/16_3-4_2006/07-715.pdf $>$.

Idowu, O., O. Cofie, and A. Adeoti. 2012. Gender analysis of land use for urban agriculture and sustainability of livelihoods in Freetown, Sierra Leone. Afr. J. Agr. Res. 7(5):676-683.

Karl, M. 1995. Women and empowerment: Participation and decision making. Zed Books, London, UK.

Kiernan, N.E., M. Barbercheck, K.J. Brasier, C Sachs, and A.R. Terman. 2012. Women farmers: Pulling up their own educational boot straps with extension. J. Ext. 50(5):5RIB5. 14 June 2016. <http://www.joe.org/joe/2012october/rb5.php?pdf $=1>$.

Klaver, D. and B. Kamphuis. 2006. Horticultural education and extension in Turkey. Wageningen University and Research Centre, Wageningen, the Netherlands.

Lu, J.L. 2010. Gender analysis of women in the Philippine agriculture and their occupational issues. J. Intl. Womens Stud. 11(4):73-82.
Meinzen-Dick, R. and A. Quisumbing. 2013. Closing the gender gap, p. 39-47. In: Global Food Policy Report 2012. Washington, DC.

Momsen, J. 2004. Introduction: Gender is a development issue, p. 1-20. In: Gender Development. Routledge, New York, NY.

Moser, C.O.N. 1993. Gender planning and development. Theory, practice and training. Routledge, New York, NY.

Nyakudya, I.W., V.J. Murewa, M.J. Mutenje, M. Moyo, T.J. Chikuvire, and R. Foti. 2006. Hidden overburden of female-headed households in guar bean production: Zimbabwean Experience. J. Intl. Women's Studies 8(1):163170

Olhan, E. 2011. Growth with decent work for all: National Youth Employment Programme and Pilot Implementation in Antalya-The Structure of Rural Employment in Turkey. United Nations Joint Programme; MDG Achievement Fund, FAO, iSKUR.

Overholt, C., M.B. Anderson, K. Cloud, and J.E. Austin. 1984. Gender roles in development Projects. Kumarian Press, West Hartford, CT.

Ozkan, B., D. Ediz, V. Ceyhan, and P. Goldey. 2000. Women's role in the vegetable farming systems in Antalya, Turkey: A gender analysis of labour participation and decision-making in the agricultural sector. Acta Hort. 536:419428.

Tsikata, D. 2009. Informalization, the informal economy and urban women's livelihoods in sub-Saharan Africa since the 1990s. In: S. Razavi (ed.). The gendered impacts of liberalization: Towards embedded liberalism? Routledge, New York, NY.

Turkish Statistical Institute (TUIK). 2015. Turkish Statistical Institute online databases. 14 June 2016. <http://www.turkstat.gov.tr/VeriBilgi. do?alt_id $=1003>$.

U.S. Department of Agriculture. 2012. Census of Agriculture 2012. U.S. Dept. Agr., Washington, DC. 14 June 2016. <http://www.agcensus. usda.gov/Publications/2012/Full_Report/Volume_ 1, Chapter_1_US/usv1.pdfs.

Uysal-Kolasin, G. and D. Guner. 2010. 4 million 742 thousand women are illiterate. Bahcesehir Univ. Center for Economic and Social Research Res. Brief 085. 14 June 2016. <http:// betam.bahcesehir.edu.tr/wp-content/uploads 2015/06/ResearchBrief085.pdf>.

Whitehead, A. 2002. Tracking livelihood change: Theoretical, methodological and empirical perspectives in north-east Ghana. J. South. Afr. Stud. 28(3):575-598.

Yamane, T. 1967. Elementary sampling theory. Prentice-Hall, Englewood Cliffs NJ.

Yilmaz, I., C. Sayin, and B. Ozkan. 2005. Turkish greenhouse industry: Past, present, and future. N. Z. J. Crop Hort. Sci. 33(3):233-240. 


\section{Supplemental Appendix}

\section{Gender analysis in vegetable farming in Antalya/Samsun, Turkey}

\begin{tabular}{ll}
\hline Name of the respondent: $\ldots \ldots \ldots \ldots \ldots \ldots \ldots \ldots \ldots \ldots$ & Date: $\ldots \ldots \ldots \ldots \ldots \ldots \ldots$ \\
\hline Province/village/street: $\ldots \ldots \ldots \ldots \ldots \ldots \ldots \ldots \ldots \ldots \ldots \ldots \ldots \ldots \ldots \ldots \ldots$
\end{tabular}

A. Household structure.

1. Identity of the respondent

(1) Female head of households (2) Wife of male head of households (3) Others (specify)

2. Age of the respondent: years old

3. Marital status of the respondent

(1) Never married (2) Formerly married (3) Currently married

4. Number of years married

(1) Less than 1 year (2) 1-5 years (3) 6-10 years (4) 11-15 years (5) $15+$ years

5. Age of the respondent's husband:

6. Educational level of the respondent

(1) Illiterate (2) Literate without diploma (3) Primary school (4) Secondary school (5) High school (6) University

7. Educational level of the husband

(1) Illiterate (2) Literate without diploma (3) Primary school

(4) Secondary school (5) High school (6) University

8. Family size (no. of persons).

\begin{tabular}{llll}
\hline Sex/age & $0-14$ & $15-64$ & $64+$ \\
\hline Female & & \\
Male
\end{tabular}

9. Number of generations in the household

(1) 1 (2) 2 (3) 3 (4) 4

10. Family members working in the vegetable production.

\begin{tabular}{ll}
\hline & \multicolumn{2}{c}{ Age } & \\
\cline { 3 - 3 } M & \\
\hline 1 & \\
2 & \\
3 & \\
4 & \\
5 & \\
6 & \\
*(1) Illiterate (2) Literate without diploma (3) \\
Primary school (4) Secondary school (5) High \\
school (6) University.
\end{tabular}

11. \% of total vegetable production consumed in the households:

12. What are the sources of information?

(1) Extension service (2) Chemical agent (3) Neighbors (4) Others (specify)

13. Can you identify three training priority areas given to you?
1).
2)
3) 
B. Activity profile

14. Distribution of the work differentiation based on sex.

\begin{tabular}{|c|c|c|c|c|c|c|c|}
\hline \multirow[b]{3}{*}{ Activities } & \multicolumn{7}{|c|}{ Total hours work per day (hours/sex/location*) } \\
\hline & \multirow[b]{2}{*}{ Respondent (hr) } & \multirow[b]{2}{*}{ Husband (hr) } & \multicolumn{5}{|c|}{ Other family members (14-64 years of age) } \\
\hline & & & $\mathrm{M} / \mathrm{F}$ & $\mathrm{M} / \mathrm{F}$ & $\mathrm{M} / \mathrm{F}$ & $\mathrm{M} / \mathrm{F}$ & $\mathrm{M} / \mathrm{F}$ \\
\hline $\begin{array}{l}\text { A. Productive } \\
\text { 1. Vegetable production }\end{array}$ & & & & & & & \\
\hline \multicolumn{8}{|l|}{$\begin{array}{l}\text { 1. Vegetable production } \\
\text { 2. Other crops production }\end{array}$} \\
\hline \multicolumn{8}{|l|}{ 3. Animal husbandry } \\
\hline \multicolumn{8}{|l|}{ 3.1. Cattle } \\
\hline \multicolumn{8}{|l|}{ 5. Marketing } \\
\hline \multicolumn{8}{|l|}{ 6. Wage work } \\
\hline \multicolumn{8}{|l|}{ 7. Craft work } \\
\hline \multicolumn{8}{|l|}{ B. Reproductive } \\
\hline \multicolumn{8}{|l|}{ 1. Food storage/processing } \\
\hline \multicolumn{8}{|l|}{ 2. Child care } \\
\hline \multicolumn{8}{|l|}{ 4. Firewood collection } \\
\hline \multicolumn{8}{|l|}{ 5. Water carrying } \\
\hline \multicolumn{8}{|l|}{ 6. House building and repair } \\
\hline 7. Others & & & & & & & \\
\hline
\end{tabular}

*H $=$ home; $\mathrm{F}=$ field; $\mathrm{LC}=$ local community; $\mathrm{OC}=$ outside community.

C. Resources/benefits profiles.

15. Gender profile of access to resources.

\begin{tabular}{|c|c|c|c|c|c|c|c|c|}
\hline \multirow{3}{*}{ Resources } & \multicolumn{8}{|c|}{ Sources of access } \\
\hline & \multirow{2}{*}{ Respondent } & \multirow{2}{*}{ Husband } & \multicolumn{6}{|c|}{ Other family members } \\
\hline & & & $\frac{1}{\mathrm{M} / \mathrm{F}}$ & $\frac{2}{M / F}$ & $\frac{3}{\mathrm{M} / \mathrm{F}}$ & $\frac{4}{\mathrm{M} / \mathrm{F}}$ & $\frac{5}{\mathrm{M} / \mathrm{F}}$ & $\frac{6}{M / F}$ \\
\hline \multirow{2}{*}{\multicolumn{9}{|c|}{$\begin{array}{l}\text { 1. Land } \\
\text { 2. Technology }\end{array}$}} \\
\hline \multirow{2}{*}{\multicolumn{9}{|c|}{$\begin{array}{l}\text { 2. Technology } \\
\text { 2.1. Mechanized }\end{array}$}} \\
\hline & & & & & & & & \\
\hline \multicolumn{9}{|l|}{ 2.2. Traditional } \\
\hline \multicolumn{9}{|l|}{ 3. Labor } \\
\hline \multicolumn{9}{|l|}{ 3.1. Family } \\
\hline \multicolumn{9}{|l|}{ 3.2. Wage } \\
\hline \multicolumn{9}{|l|}{ 4. Capital } \\
\hline \multicolumn{9}{|l|}{ 5. Cooperatives } \\
\hline \multicolumn{9}{|l|}{ 6. Credit } \\
\hline \multicolumn{9}{|l|}{ 7. Cattle } \\
\hline 8. Small animals & & & & & & & & \\
\hline
\end{tabular}

16. Gender profile of control over resources.

\begin{tabular}{|c|c|c|c|c|c|c|c|c|}
\hline \multirow[b]{4}{*}{ Resources } & \multicolumn{8}{|c|}{ Sources of control } \\
\hline & \multirow[b]{3}{*}{ Respondent } & \multirow[b]{3}{*}{ Husband } & \multicolumn{6}{|c|}{ Other family members } \\
\hline & & & 1 & 2 & 3 & 4 & 5 & 6 \\
\hline & & & $\overline{\mathrm{M} / \mathrm{F}}$ & $\overline{\mathrm{M} / \mathrm{F}}$ & $\overline{\mathrm{M} / \mathrm{F}}$ & $\overline{\mathrm{M} / \mathrm{F}}$ & $\overline{\mathrm{M} / \mathrm{F}}$ & $\overline{\mathrm{M} / \mathrm{F}}$ \\
\hline \multirow{2}{*}{\multicolumn{9}{|c|}{$\begin{array}{l}\text { 1. Land } \\
\text { 2. Technology }\end{array}$}} \\
\hline & \\
\hline \multicolumn{9}{|l|}{ 2.1. Mechanized } \\
\hline \multicolumn{9}{|l|}{ 2.2. Traditional } \\
\hline \multicolumn{9}{|l|}{ 3. Labor } \\
\hline \multicolumn{9}{|l|}{ 3.1. Family } \\
\hline \multicolumn{9}{|l|}{ 3.2. Wage } \\
\hline \multicolumn{9}{|l|}{ 4. Capital } \\
\hline \multicolumn{9}{|l|}{ 5. Cooperatives } \\
\hline \multicolumn{9}{|l|}{ 6. Credit } \\
\hline \multicolumn{9}{|l|}{ 7. Cattle } \\
\hline 8. Small animals & & & & & & & & \\
\hline
\end{tabular}


17. Gender profile benefit and use.

\begin{tabular}{lllllllll}
\hline & \multicolumn{1}{c}{ Sources of benefits and use* } \\
\cline { 2 - 7 } & & & \multicolumn{5}{c}{ Other family members } \\
\cline { 2 - 7 } Resources & Respondent & Husband & $\frac{1}{\mathrm{M} / \mathrm{F}}$ & $\frac{2}{\mathrm{M} / \mathrm{F}}$ & $\frac{3}{\mathrm{M} / \mathrm{F}}$ & $\frac{4}{\mathrm{M} / \mathrm{F}}$ & $\frac{5}{\mathrm{M} / \mathrm{F}}$ & $\frac{6}{\mathrm{M} / \mathrm{F}}$ \\
\hline 1. Land & & & & & & & \\
2. Technology & & & & & & \\
2.1. Mechanized \\
2.2. Traditional \\
3. Labor \\
3.1. Family \\
3.2. Wage \\
4. Capital \\
5. Cooperatives \\
6. Credit \\
7. Cattle \\
8. Small animals \\
*Food, income, skills, land rights, and status.
\end{tabular}

D. Development constraints.

18. Which are the most important constraints $(1=$ most important, $4=$ least important $)$.

\begin{tabular}{ll}
\hline ( ) Lack of credit access & ( ) Lack of extension access \\
( ) Lack of markets & ( ) Land tenure \\
( ) Low labor productivity & ( ) Poor legal structure \\
( ) Others (specify) & ( ) Lack of skilled personnel \\
( ) Illiteracy & ( ) Deforestation \\
( ) Poor health & ( ) Poor resource base \\
( ) Cultural attitudes/taboos & ( ) Drought \\
( ) High birth rates & ( ) Erosion \\
\hline
\end{tabular}

E. Income-generating activities and savings.

19. Distribution of the family income sources.

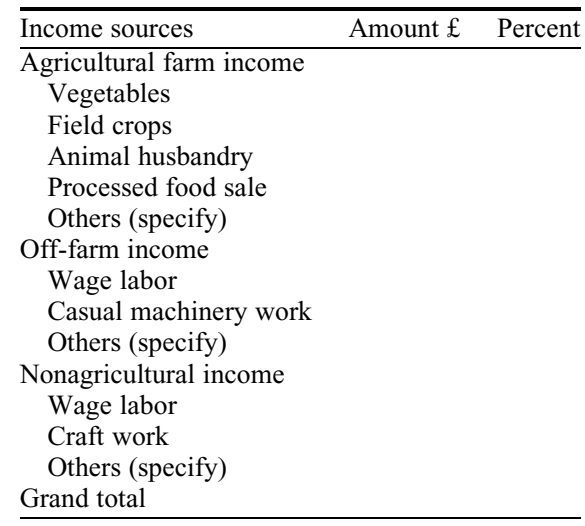

20. Saving profile.

\begin{tabular}{|c|c|c|c|c|c|c|c|c|}
\hline \multirow[b]{4}{*}{ Saving profile } & \multicolumn{8}{|c|}{ Sources of savings } \\
\hline & \multirow[b]{3}{*}{ Respondent } & \multirow[b]{3}{*}{ Husband } & \multicolumn{6}{|c|}{ Other family members } \\
\hline & & & 1 & 2 & 3 & 4 & 5 & 6 \\
\hline & & & $\overline{\mathrm{M} / \mathrm{F}}$ & $\overline{\mathrm{M} / \mathrm{F}}$ & $\overline{\mathrm{M} / \mathrm{F}}$ & $\overline{\mathrm{M} / \mathrm{F}}$ & $\overline{\mathrm{M} / \mathrm{F}}$ & $\overline{\mathrm{M} / \mathrm{F}}$ \\
\hline \multicolumn{9}{|l|}{ Bank account } \\
\hline \multicolumn{9}{|l|}{ Buying gold } \\
\hline \multicolumn{9}{|c|}{ Buying foreign currency } \\
\hline \multicolumn{9}{|l|}{ Buying stock } \\
\hline Others (specify) & & & & & & & & \\
\hline
\end{tabular}

